Technical Note

\title{
Removal of Hydrogen Sulfide from Biogas Using a Bubbling Tank Fed with Aerated Wastewater
}

\author{
Hsiu-Wen Ou ${ }^{1,2}$, Ming-Shean Chou ${ }^{1}$, Hsiao-Yu Chang ${ }^{*}$ \\ ${ }^{1}$ Institute of Environmental Engineering, National Sun Yat-sen University, Kaohsiung 80424, Taiwan \\ ${ }^{2}$ Livestock Research Institute, Council of Agriculture, Executive Yuan, Tainan 71246, Taiwan
}

\begin{abstract}
The work develops a simple bubbling tank scrubber that is fed with aerating wastewater for the removal of hydrogen sulfide $\left(\mathrm{H}_{2} \mathrm{~S}\right)$ in biogas. A 2,000 L plastic tank, in which fixed liquid levels 0.80 and $1.0 \mathrm{~m}$ and volumes of 1.1 and $1.4 \mathrm{~m}^{3}$ was kept, was used for the scrubbing tests. A polyvinyl chloride (PVC) pipe with holes of $1 \mathrm{~mm}$ diameter was used to sparge the biogas into the tank liquid. Results indicate that with an influent liquid of $\mathrm{pH} 7.5-7.7$, a flow rate of $23-25 \mathrm{~L} \mathrm{~min}^{-1}$, influent biogas flow rates of $0.050-0.200 \mathrm{~m}^{3} \mathrm{~min}^{-1}$, and a $\mathrm{H}_{2} \mathrm{~S}$ concentration of $907 \pm 212 \mathrm{ppm}$, the pH of the effluent liquid stabilized at 6.6-6.9. With gas/liquid rate ratio of $2-8 \mathrm{~m}^{3} \mathrm{~m}^{-3}$ liquid and volumetric gassing intensities of $0.04-0.20 \mathrm{~m}^{3} \mathrm{~m}^{-3}$ liquid $\mathrm{min}^{-1}$, average $\mathrm{H}_{2} \mathrm{~S}$ removals of $86-71 \%$ were obtained. Absorption of $\mathrm{CO}_{2}$ in the tested digester gas into the scrubbing liquid caused a decrease in the $\mathrm{pH}$, thus decreasing the $\mathrm{H}_{2} \mathrm{~S}$ removal efficiency. Increasing $\mathrm{pH}$ of the scrubbing liquid to 8.0 improved the $\mathrm{H}_{2} \mathrm{~S}$ removal efficiency to as high as $99 \%$.
\end{abstract}

Keywords: Hydrogen sulfide; Bubbling scrubbing; Digester gas; Air pollution control.

\section{INTRODUCTION}

Biogas contains $\mathrm{H}_{2} \mathrm{~S}$ which is corrosive to power generators and other metal components. The presence of $\mathrm{H}_{2} \mathrm{~S}$ is a concern to not only owners of anaerobic digesters but also workers in biogas plants. $\mathrm{H}_{2} \mathrm{~S}$ reacts with oxygen in air to form $\mathrm{H}_{2} \mathrm{SO}_{4}$, which is corrosive to most metals in the presence of water. Sulfate in air is also a main component of secondary inorganic aerosols in the atmosphere (Jiang et al., 2018; Li et al., 2018a; Li et al., 2018b; Tseng et al., 2019)

Another concern is the conversion of $\mathrm{H}_{2} \mathrm{~S}$ to sulfur dioxide $\left(\mathrm{SO}_{2}\right)$ during the combustion of biogas in power generator (Potivichayanon et al., 2006; Beristain-Cardoso et al., 2008; Krischan et al., 2012; Smith and Ndegwa, 2012; Solcia et al., 2014). Thus, the presence of $\mathrm{H}_{2} \mathrm{~S}$ has been identified as a technological barrier to the production and utilization of biogas.

Techniques for removing $\mathrm{H}_{2} \mathrm{~S}$ from biogas or industrial waste gases comprise physical, chemical, and biological methods. Chemical methods, such as the oxidative absorption of $\mathrm{H}_{2} \mathrm{~S}$ into an aqueous solution of ferric sulfate, involve expensive chemicals or require the management of the sulfur slurry that is formed from $\mathrm{H}_{2} \mathrm{~S}$ (Krischan et al., 2010;

\footnotetext{
* Corresponding author.

Tel.: 88675254428

E-mail address: d9033803@student.nsysu.edu.tw
}

Liu and Wang, 2017, 2019; Pei and Wang, 2019). Physical methods, such as water scrubbing or adsorption, require the replacement of saturated scrubbing water or activated carbon (Pipatmanomai et al., 2009; Lien et al., 2014; Huang et al., 2019; Mao et al., 2020). In terms of microbiological methods, the removal of $\mathrm{H}_{2} \mathrm{~S}$ has been intensively studied. Most studies have focused on fixed-film processes such as the use of biofilters (BFs), or biotrickling filters (BTFs), and bioscrubbing towers (BSTs) (Gadre, 1989; Nitta and Hirura, 1993; Yang and Allen, 1994; Jensen and Webb, 1995; Nishimura and Motoyuki, 1997; Potivichayanon et al., 2006; Liang and Liang, 2013; Lin et al., 2013; Su et al., 2013; Solcia et al., 2014; Su et al., 2014).

$\mathrm{H}_{2} \mathrm{~S}$ in a gas stream can also be removed by bubbling the stream through gas spargers into an activated sludge tank. Water-soluble $\mathrm{H}_{2} \mathrm{~S}$ is absorbed into the mixed liquor and subsequently degraded by the microorganisms in the liquor (Sublette et al., 1994; Chou et al., 2010). The bubbling method can be easily applied when the activated sludge system is located near the waste gas stream(s). The process can be used to remove $\mathrm{H}_{2} \mathrm{~S}$ in gases that are emitted from anaerobic digesters, landfill fields, lift wells for sewage treatment, and paper and pulp plants (Syed et al., 2006; Zhang et al., 2018). Sublette et al. (1994) developed a process that uses flocculated Thiobacillus denitrificans to remove up to $1,500 \mathrm{ppm}$ of $\mathrm{H}_{2} \mathrm{~S}$ from sour gas. Using a $0.5-\mathrm{m}^{3}$ pilot-scale bubble column, up to $97 \%$ of $\mathrm{H}_{2} \mathrm{~S}$ was removed by complete oxidation to sulfate, which accumulated in the reactor medium. $\mathrm{H}_{2} \mathrm{~S}$ removal was 
limited by mass transfer rather than the biodegradation rate of the system. Amano et al. (1999) used a suspension of $T$. thiooxidans with sodium citrate as a buffering agent to remove $\mathrm{H}_{2} \mathrm{~S}$ from a gas stream. They obtained a removal rate of $0.96 \mathrm{~g} \mathrm{H}_{2} \mathrm{~S} \mathrm{~m}^{-3} \mathrm{~d}^{-1}$. Shimko et al. (1987) also proposed a patented process that involves bubbling a gas stream with $1,700-5,400 \mathrm{mg} \mathrm{H}_{2} \mathrm{~S} \mathrm{~m}^{-3}$ and 1,800-5,100 $\mathrm{mg} \mathrm{CS}_{2} \mathrm{~m}^{-3}$ into an activated sludge tank with a liquor depth of 3-4 m. Chou et al. (2010) used an activated sludge aeration tank (width $\times$ length $\times$ height $=0.4 \mathrm{~m} \times 0.4 \mathrm{~m} \times 3 \mathrm{~m}$ ) with a $2 \mathrm{~mm}$-orifice air sparger to treat gaseous $\mathrm{H}_{2} \mathrm{~S}$. They tested the operational stability and the relationships between the removal of $\mathrm{H}_{2} \mathrm{~S}$ and the influent $\mathrm{H}_{2} \mathrm{~S}$ concentration (50-900 ppm), aeration intensity $\left(0.083-0.50 \mathrm{~m}^{3} \mathrm{~m}^{-3} \mathrm{~min}^{-1}\right)$, liquid depth $(0.5-3 \mathrm{~m})$, and concentration of mixed-liquor-suspended solids (MLSS $\left.=970-2,800 \mathrm{mg} \mathrm{L}^{-1}\right)$. They experimentally obtained $\mathrm{H}_{2} \mathrm{~S}$ removal efficiencies of $96 \%$ and $<98 \%$ at liquid depth values of $0.5 \mathrm{~m}$ and $<1 \mathrm{~m}$, respectively, under their specified operational conditions. Their experimental results also revealed that no sludge bulking problem occurred at total sulfide loadings of 47-148 $\mathrm{g} \mathrm{S} \mathrm{kg}^{-1}$ MLSS.d $\mathrm{d}^{-1}$.

The bubbling approach requires a column or tank fed with a stream of activated sludge liquor that may be supplied from an existing aerating pond or fed with supplemental nutrients (such as carbon, nitrogen, and phosphorus) to sustain the microorganisms that oxidize the absorbed sulfide. This requirement limits the practical application of the approach because considerable attention must be paid to maintaining the health of the microorganisms.

This study developed a simple bubbling tank scrubber that is fed with aerated wastewater for the removal of $\mathrm{H}_{2} \mathrm{~S}$ from biogas that is vented from anaerobic digesters used to treat wastewater from dairy farms. The effects of the bubbling rate, liquid depth, and the $\mathrm{pH}$ of the scrubbing liquid on the degree and rate of $\mathrm{H}_{2} \mathrm{~S}$ removal were investigated.

\section{METHODS}

The experimental setup comprised a full-scale bubbling tank and an influent gas supply system (Figs. 1 and 2). A 2,000$\mathrm{L}$ plastic tank with an inner diameter of $1.33 \mathrm{~m}$; fixed water levels of $0.80-1.0 \mathrm{~m}$; and 1,100-1,400 $\mathrm{L}$ of scrubbing liquid was used for the scrubbing tests. A 2-inch polyvinyl chloride (PVC) perforated pipe was formed into a rectangle and used to sparge the biogas into the tank liquid. A total of 536 holes with a diameter of $1 \mathrm{~mm}$ and a constant pitch of $10 \mathrm{~mm}$ were present along the pipe, and four holes were present $90^{\circ}$ apart along the perimeter of the pipe. Biogas from the digesters of a dairy wastewater plant was collected in a full-scale plastic bag. The biogas was filtered and then passed through a ringtype blower and sparged into the tank liquid. Aerating wastewater for the aerobic treatment of the effluent from anaerobic digesters was fed into the tank as a scrubbing liquid and flowed over the tank into the aerobic pond under the influence of gravity. Flow rates of both the gas and scrubbing liquid were regulated using rotameters.
(1) Untreated digester gas bag

(2) Digester gas filter

(3) Untreated digester gas back flow pipe

(4) Treated digester gas back flow pipe

(5) Ring blower

6) Sampling port for untreated digester gas

(7) Drain pipe

(8) Gas flow meter $(0-300 \mathrm{~L} / \mathrm{min})$
(9) Desulfurization aeration tank (2000L)

(10) Treated digester gas

(11) Sampling port for treated digester gas

(12) Treated digester gas to generator

(13) Liquid from activated sludge aeration tank

(14) Liquid flow meter $(0-50 \mathrm{~L} / \mathrm{min})$

(15) Liquid over flow pipe

(16) Liquid drained to the effluent sedimentation tank

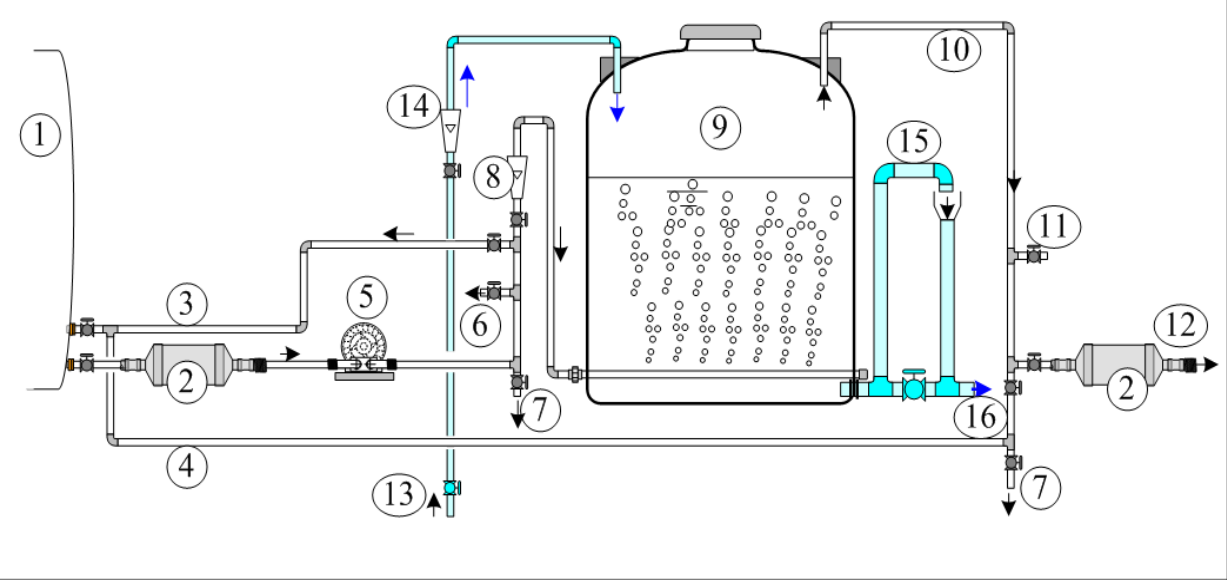

Fig. 1. Schematics of the experimental system. 

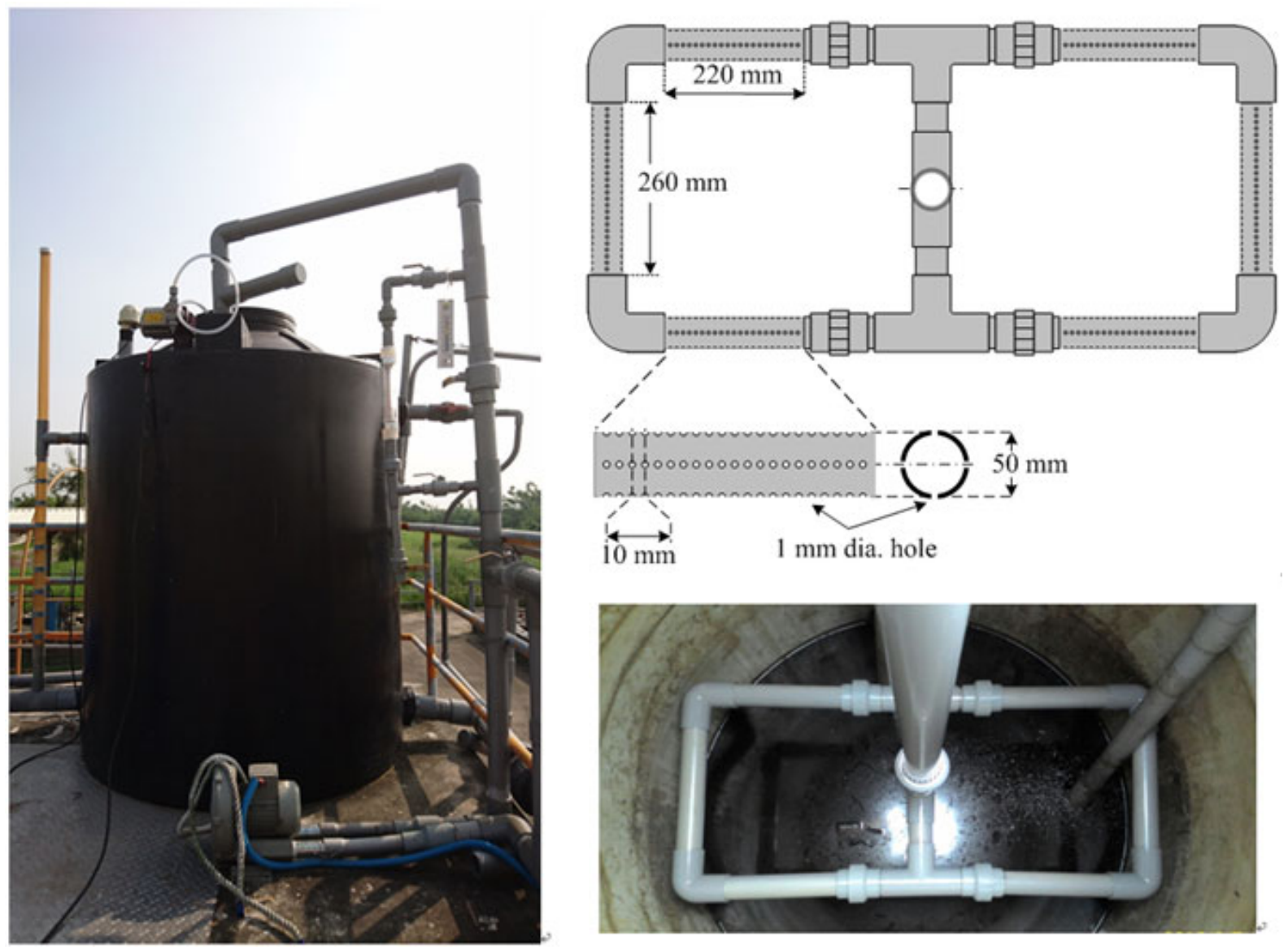

Fig. 2. The experimental bubbling tank and the gas sparger.

Initially, the tank was filled to a certain depth with the scrubbing liquid that was drawn from one of the aeration tanks; subsequently, the scrubbing liquid flow rate was adjusted to a preset value. A stream of biogas was then introduced into the tank and the flow rate was adjusted to a present value. $\mathrm{H}_{2} \mathrm{~S}$ concentrations in the influent and effluent biogas and the $\mathrm{pH}$ of the effluent scrubbing liquid were measured at the end of 10-min fixed intervals until both the $\mathrm{H}_{2} \mathrm{~S}$ concentration of the effluent biogas and the $\mathrm{pH}$ of the effluent scrubbing liquid reached quasi-steady values. Temperatures of the scrubbing liquid and gas were also measured during the operation. Concentrations of chemical oxygen demand (COD), suspended solids (SS), total solids (TS), dissolved oxygen (DO), and the basicity of the influent scrubbing liquid were measured during several runs.

Aqueous hydrogen sulfide has a $K_{\mathrm{a}}$ of 7.1 at $25^{\circ} \mathrm{C}$ in the following ionization reaction: $\mathrm{H}_{2} \mathrm{~S}_{(\mathrm{aq})} \leftrightarrows \mathrm{HS}^{-}+\mathrm{H}^{+}$. Consistent with this $\mathrm{p} K_{\mathrm{a}}$ value, at $\mathrm{pH} 7,55.7 \%$ of the total aqueous hydrogen sulfide $\left(\left[\mathrm{H}_{2} \mathrm{~S}_{(\mathrm{aq})}\right]+\left[\mathrm{HS}^{-}\right]\right)$is in an un-ionized state: $\alpha=\left[\mathrm{H}_{2} \mathrm{~S}_{(\mathrm{aq})}\right] /\left(\left[\mathrm{H}_{2} \mathrm{~S}_{(\mathrm{aq})}\right]+\left[\mathrm{HS}^{-}\right]\right)=1 /\left(1+10^{7-7.1}\right)=0.557$. At a higher $\mathrm{pH}$, such as $8, \alpha=1 /\left(1+10^{8-7.1}\right)=0.112$. Thus, a scrubbing liquid with a higher $\mathrm{pH}$ and acidic buffering capacity favors the chemical absorption of $\mathrm{H}_{2} \mathrm{~S}$. In the present study, for some cases, the scrubbing liquid was supplemented with sodium hydroxide solution (45\%) by a dosing pump that was actuated by a $\mathrm{pH}$ controller to a preset $\mathrm{pH}$ range to test the effect of $\mathrm{pH}$ on $\mathrm{H}_{2} \mathrm{~S}$ removal efficiency. Either calcium or magnesium hydroxide can also be used for $\mathrm{pH}$ control. However, $\mathrm{CaCO}_{3}$ or $\mathrm{MgCO}_{3}$ solids may form and precipitate in the scrubbing liquid and interfere with the operation. Sodium bicarbonate and carbonate are more expensive than sodium hydroxide.

$\mathrm{H}_{2} \mathrm{~S}$ concentrations in the gas samples were measured using detection tubes $\left(\mathrm{H}_{2} \mathrm{~S}\right.$ detector tubes, Gastec Corporation, Japan) and a portable multiple gas analyzer (Dräger X-am 7000, Dräger Safety AG \& Co. KGaA, Germany). The gas analyzer could also provide data on gaseous $\mathrm{CH}_{4}, \mathrm{CO}_{2}$, and $\mathrm{O}_{2}$. Data from 25 samples of the influent digester gas to the tank indicated $\mathrm{CH}_{4}, \mathrm{CO}_{2}$, and $\mathrm{O}_{2}$ contents of $64.5 \pm 2.7 \%$, $28.2 \pm 1.5 \%$, and $0.53 \pm 0.22 \%$, respectively, and $\mathrm{H}_{2} \mathrm{~S}$ content was $1090 \pm 300 \mathrm{ppm}$. The detected gases accounted for $>93 \%$ of all the components, with the remaining gases likely to be $\mathrm{N}_{2}, \mathrm{H}_{2} \mathrm{O}, \mathrm{NH}_{3}$, and $\mathrm{H}_{2}$ (Seadi et al., 2008). Both detection tubes and the analyzer were calibrated using standard $\mathrm{H}_{2} \mathrm{~S}$ gas at concentrations of 5, 10, 20, and $50 \mathrm{ppm}$. Liquid $\mathrm{pH}$ was detected using a $\mathrm{pH}$ meter $(\mathrm{pH} / \mathrm{mV}$ Pocker Meter $\mathrm{pH}$ 330i, WTW, Germany), and COD, SS, TSS, DO, and basicity were measured according to the APHA (1989).

\section{RESULTS AND DISCUSSION}

Table 1 details the scrubbing liquid qualities and Table 2 details the properties of the raw and scrubbed biogases of the present study. 
Table 1. Scrubbing liquid qualities.

\begin{tabular}{lll}
\hline & Influent & Effluent \\
\hline Chemical oxygen demand, COD $\left(\mathrm{mg} \mathrm{L}^{-1}\right)$ & $817 \pm 67$ & $797 \pm 80$ \\
Suspended solids, SS (mg L & $262 \pm 35$ & $225 \pm 28$ \\
Total solids, TS $\left(\mathrm{mg} \mathrm{L}^{-1}\right)$ & $2160 \pm 181$ & $2160 \pm 154$ \\
Dissolved oxygen, DO $\left(\mathrm{mg} \mathrm{L}^{-1}\right)$ & $0.10 \pm 0.02$ & - \\
Basicity (titration to $\mathrm{pH} 7.00)\left(\mathrm{meq} \mathrm{L}^{-1}\right)$ & $6.13 \pm 0.33$ & - \\
\hline
\end{tabular}

Table 2. Some operation data.

\begin{tabular}{|c|c|c|c|c|c|c|c|c|c|c|c|c|}
\hline \multirow[b]{2}{*}{$\begin{array}{l}\text { flowrate } \\
\left(\mathrm{L} \mathrm{min}^{-1}\right)\end{array}$} & \multicolumn{4}{|c|}{ Influent biogas to the tank } & \multicolumn{5}{|c|}{ Effluent biogas@guasi-steady state } & \multirow{2}{*}{$\begin{array}{l}\text { Influent } \\
\text { scrubbing } \\
\text { liquid } \\
\mathrm{pH}\end{array}$} & \multicolumn{2}{|c|}{$\begin{array}{c}\text { Effluent } \\
\text { scrubbing } \\
\text { liquid }\end{array}$} \\
\hline & $\begin{array}{l}\mathrm{CH}_{4} \\
(\%)\end{array}$ & $\begin{array}{l}\mathrm{CO}_{2} \\
(\%)\end{array}$ & $\begin{array}{l}\mathrm{O}_{2} \\
(\%)\end{array}$ & $\begin{array}{l}\mathrm{H}_{2} \mathrm{~S} \\
(\mathrm{ppm})\end{array}$ & $\begin{array}{l}\mathrm{T} \\
\left({ }^{\circ} \mathrm{C}\right)\end{array}$ & $\begin{array}{l}\mathrm{CH}_{4} \\
(\%)\end{array}$ & $\begin{array}{l}\mathrm{CO}_{2} \\
(\%)\end{array}$ & $\begin{array}{l}\mathrm{O}_{2} \\
(\%)\end{array}$ & $\begin{array}{l}\mathrm{H}_{2} \mathrm{~S} \\
(\mathrm{ppm})\end{array}$ & & $\mathrm{pH}$ & $\begin{array}{l}\mathrm{T} \\
\left({ }^{\circ} \mathrm{C}\right)\end{array}$ \\
\hline \multirow[t]{3}{*}{50} & 68 & 27 & 0.7 & 570 & 34.0 & 66 & 21 & 0.8 & 21 & 7.78 & 7.04 & 24.6 \\
\hline & 63 & 29 & 0.8 & 1,410 & 34.0 & 65 & 26 & 0.6 & 68 & 7.73 & 7.19 & 31.4 \\
\hline & 68 & 29 & 0.6 & 1,480 & 34.0 & 63 & 25 & 0.8 & 206 & 7.99 & 7.14 & 31.2 \\
\hline \multirow[t]{2}{*}{60} & 60 & 29 & 0.8 & 1,150 & 40.2 & 63 & 28 & 0.4 & 182 & 7.89 & 7.07 & 33.1 \\
\hline & 62 & 30 & 0.5 & 1,055 & 40.5 & 64 & 29 & 0.4 & 177 & 7.92 & 6.98 & 33.9 \\
\hline \multirow[t]{8}{*}{100} & 65 & 25 & 0.4 & 1,020 & 30.0 & 70 & 23 & 0.4 & 156 & 7.78 & 6.93 & 23.8 \\
\hline & 70 & 26 & 0.6 & 870 & 33.8 & 68 & 23 & 0.7 & 151 & 7.63 & 6.95 & 24.0 \\
\hline & 66 & 26 & 0.8 & 570 & 31.0 & 65 & 24 & 1.1 & 62 & 7.67 & 6.95 & 24.8 \\
\hline & 63 & 30 & 0.4 & 890 & 42.5 & 64 & 27 & 0.4 & 164 & 7.85 & 6.94 & 32.2 \\
\hline & 63 & 29 & 0.6 & 1,510 & 39.0 & 64 & 27 & 0.3 & 236 & 7.95 & 7.04 & 31.8 \\
\hline & 63 & 27 & 0.8 & 1,395 & 35.6 & 60 & 26 & 0.5 & 195 & 7.93 & 7.04 & 31.4 \\
\hline & 62 & 28 & 0.5 & 1,190 & 37.0 & 64 & 26 & 0.4 & 170 & 7.92 & 7.11 & 32.0 \\
\hline & 62 & 29 & 0.5 & 1,290 & 36.0 & 63 & 29 & 0.4 & 230 & 7.96 & 7.02 & 33.1 \\
\hline \multirow[t]{5}{*}{150} & 66 & 29 & 0.4 & 890 & 29.0 & 68 & 26 & 0.4 & 189 & 7.60 & 6.68 & 24.0 \\
\hline & 70 & 26 & 0.6 & 1,320 & 30.5 & 70 & 25 & 0.3 & 464 & 7.75 & 6.84 & 24.8 \\
\hline & 63 & 29 & 0.4 & 800 & 39.4 & 62 & 25 & 0.6 & 164 & 7.93 & 7.11 & 32.2 \\
\hline & 61 & 29 & 1 & 1,245 & 40.2 & 64 & 29 & 0.3 & 244 & 8.06 & 7.12 & 33.3 \\
\hline & 68 & 26 & 0.6 & 1,310 & 26.0 & 66 & 25 & 0.4 & 360 & 7.31 & 6.60 & 25.0 \\
\hline \multirow[t]{5}{*}{200} & 66 & 29 & 0 & 620 & 25.5 & 68 & 29 & 0.4 & 166 & 7.58 & 6.70 & 24.5 \\
\hline & 68 & 29 & 0.2 & 1,410 & 39.0 & 66 & 27 & 0 & 414 & 7.68 & 6.68 & 25.8 \\
\hline & 64 & 27 & 0.5 & 1,390 & 43.6 & 64 & 27 & 0.5 & 228 & 8.02 & 7.07 & 32 \\
\hline & 63 & 30 & 0.4 & 915 & 42.4 & 66 & 27 & 0.3 & 195 & 7.97 & 7.07 & 32.1 \\
\hline & 61 & 29 & 0.3 & 1,330 & 36.2 & 60 & 29 & 0.7 & 278 & 7.94 & 6.98 & 32.8 \\
\hline
\end{tabular}

In general, the mechanistic model developed by Bielefeldt and Stensel (1999) describes the removal of VOCs from a contaminated gas stream sparged into a completely mixed activated sludge reactor as a function of the gas-liquid mass transfer and liquid VOC concentrations. The model can be modified and applied to the present system as follows:

$\mathrm{C}-m x=\left(\mathrm{C}_{\mathrm{o}}-m x\right) \exp \left[-\mathrm{K}_{\mathrm{G}} \mathrm{aZ} /(\mathrm{G} / \mathrm{A})\right]$

where $\mathrm{C}$ and $\mathrm{C}_{\mathrm{o}}$ represent $\mathrm{H}_{2} \mathrm{~S}$ concentrations in the exit and the influent biogas streams $\left(\mathrm{mg} \mathrm{m}^{-3}\right)$, respectively; $m$ is the dimensionless Henry's law coefficient; $x$ is the molecular $\mathrm{H}_{2} \mathrm{~S}$ concentration in the liquid phase $\left(\mathrm{mg} \mathrm{m}^{-3}\right)$; $\mathrm{K}_{\mathrm{G}} \mathrm{a}$ is the overall volumetric mass transfer coefficient of $\mathrm{H}_{2} \mathrm{~S}$ in biogas $\left(\mathrm{min}^{-1}\right) ; \mathrm{Z}$ is the depth of the liquid over the sparger $(\mathrm{m}) ; \mathrm{G}$ is the influent gas flow rate $\left(\mathrm{m}^{3} \mathrm{~min}^{-1}\right)$, and $\mathrm{A}$ is the crosssectional area of the sparging tank $\left(\mathrm{m}^{2}\right)$. In liquid phase, molecular hydrogen sulfide ionizes according to the following equations:

$$
\begin{aligned}
& \mathrm{H}_{2} \mathrm{~S} \rightarrow \mathrm{HS}^{-}+\mathrm{H}^{+} \\
& \frac{\left[\mathrm{H}^{+}\right]\left[\mathrm{HS}^{-}\right]}{\left[\mathrm{H}_{2} \mathrm{~S}\right]}=K_{a 1}=7.94 \times 10^{-8} \mathrm{M} \quad\left(p K_{a 1}=7.1\right)
\end{aligned}
$$

$$
\begin{aligned}
& \mathrm{HS}^{-} \rightarrow \mathrm{S}^{2-}+\mathrm{H}^{+} \\
& \frac{\left[\mathrm{H}^{+}\right]\left[\mathrm{S}^{2-}\right]}{\left[\mathrm{HS}^{-}\right]}=K_{a 2}=10^{-14} \mathrm{M} \quad\left(p K_{a 2}=14\right)
\end{aligned}
$$

Un-dissociated or molecular $\mathrm{H}_{2} \mathrm{~S}$ in water $\left(x\right.$ or $\left.\left[\mathrm{H}_{2} \mathrm{~S}\right]\right)$ can then be related to the total sulfide $\left(\left[\mathrm{H}_{2} \mathrm{~S}\right]+\left[\mathrm{HS}^{-}\right]+\left[\mathrm{S}^{2-}\right]\right)$ in water by the following equation:

$$
f=\frac{\left[\mathrm{H}_{2} \mathrm{~S}\right]}{\left[\mathrm{H}_{2} \mathrm{~S}\right]+\left[\mathrm{HS}^{-}\right]+\left[\mathrm{S}^{2-}\right]}=\frac{\left[\mathrm{H}^{+}\right]^{2}}{\left[\mathrm{H}^{+}\right]^{2}+\left[\mathrm{H}^{+}\right] K_{a 1}+K_{a 1} K_{a 2}}
$$


Table 3 shows dependence of $f$ on water $\mathrm{pH}$. Water with a higher $\mathrm{pH}$ gives a lower $x$ or $\left[\mathrm{H}_{2} \mathrm{~S}\right]$ value which favors the absorption of gaseous $\mathrm{H}_{2} \mathrm{~S}$, according to Eq. (1). In addition, molecular or ionized $\mathrm{H}_{2} \mathrm{~S}$ in the liquid may be chemically or biologically oxidized to elementary sulfur, sulfite, or sulfate by utilizing molecular oxygen in the liquid. The reactions help to gaseous $\mathrm{H}_{2} \mathrm{~S}$ removal by enhancing its transfer to the liquid.

According to Eq. (1), bubbling gas flow rate (G), influent gas $\mathrm{H}_{2} \mathrm{~S}$ concentration $\left(\mathrm{C}_{\mathrm{o}}\right)$, liquid depth $(\mathrm{Z})$, mass-transfer coefficient $\left(\mathrm{K}_{\mathrm{G}} \mathrm{a}\right)$, molecular $\mathrm{H}_{2} \mathrm{~S}$ concentration in the liquid phase ( $x$, depends on $\mathrm{pH}$ ), and $m$ (depends mainly on liquid temperature) are among the affecting factors to the $\mathrm{H}_{2} \mathrm{~S}$ removal. In the present study, effects of $\mathrm{G}$, liquid $\mathrm{pH}$, and $\mathrm{Z}$ on the $\mathrm{H}_{2} \mathrm{~S}$ removal were tested and results discussed. Effect of $\mathrm{C}_{\mathrm{o}}$ on the removal was also discussed.

\section{Effects of Bubbling Rate, Scrubbing Liquid pH, and Depth on $\mathrm{H}_{2} \mathrm{~S}$ Removal}

Fig. 3 details the variations in $\mathrm{H}_{2} \mathrm{~S}$ removal and liquid $\mathrm{pH}$ over time during operation at a liquid depth $(Z)$ of $0.8 \mathrm{~m}$ and gas injection rates $(G)$ of $0.050,0.100$, and $0.200 \mathrm{~m}^{3} \mathrm{~min}^{-1}$. When $G$ was $0.050 \mathrm{~m}^{3} \mathrm{~min}^{-1}$ at $30-32^{\circ} \mathrm{C}$ or when the volumetric gassing intensity $(G / V)$ (gas injection rate per unit liquid volume) was $0.0455 \mathrm{~m}^{3} \mathrm{~m}^{-3} \cdot \mathrm{min}^{-1}, \mathrm{H}_{2} \mathrm{~S}$ removal was $86.4 \% \pm 8.9 \%$ at $\mathrm{pH} 6.92 \pm 0.12$ for an influent $\mathrm{H}_{2} \mathrm{~S}$ concentration of $918 \pm 18 \mathrm{ppm}$ and a scrubbing liquid influent flow rate of $25 \pm 1 \mathrm{~L} \mathrm{~min}^{-1}$ in the quasi-steady state. As the gas injection rate increased from 0.050 to $0.200 \mathrm{~m}^{3} \mathrm{~min}^{-1}$, the proportion of $\mathrm{H}_{2} \mathrm{~S}$ removed was reduced from $86.4 \% \pm$ $8.9 \%$ to $70.6 \% \pm 1.1 \%$, and the $\mathrm{pH}$ of the scrubbing liquid decreased from $6.92 \pm 0.12$ to $6.75 \pm 0.11$. The influent $\mathrm{H}_{2} \mathrm{~S}$ concentration did not affect its removal efficiency (Fig. 3). At the influent $\mathrm{H}_{2} \mathrm{~S}$ concentrations of 620 and $1,410 \mathrm{ppm}$, the removal efficiency was approximately $70 \%$, and the $\mathrm{pH}$ was 6.75 at the end of each operation (Fig. 3(c)). This could be because the efficiency was mass-transfer-controlled when the influent $\mathrm{H}_{2} \mathrm{~S}$ concentration increased from 620 to 1410 ppm and the removal efficiency remained constant (at around $70 \%$ ) (Chou et al., 2010). Increase in the biogas injection flow rate, which reduced the $\mathrm{pH}$ of the scrubbing liquid, affected the removal efficiency of $\mathrm{H}_{2} \mathrm{~S}$.

Fig. 4 details the time variations in the mean proportions of $\mathrm{H}_{2} \mathrm{~S}$ removed and the liquid $\mathrm{pH}$ in the operations where $G$ $=0.150 \mathrm{~m}^{3} \mathrm{~min}^{-1}$ and $Z$ was $0.8,0.9$, and $1 \mathrm{~m}$. Higher $\mathrm{pH}$ values of the influent and effluent liquid were associated with the removal of a higher amount of $\mathrm{H}_{2} \mathrm{~S}$.

Table 3. Dependence of $f$ on water $\mathrm{pH}$.

\begin{tabular}{ll}
\hline $\mathrm{pH}$ & $f=\frac{\left[\mathrm{H}_{2} \mathrm{~S}\right]}{\left[\mathrm{H}_{2} \mathrm{~S}\right]+\left[\mathrm{HS}^{-}\right]+\left[\mathrm{S}^{2-}\right]}$ \\
\hline 6.50 & 0.799 \\
7.00 & 0.557 \\
7.50 & 0.285 \\
8.00 & 0.112 \\
8.50 & 0.0383 \\
9.00 & 0.0124 \\
\hline
\end{tabular}
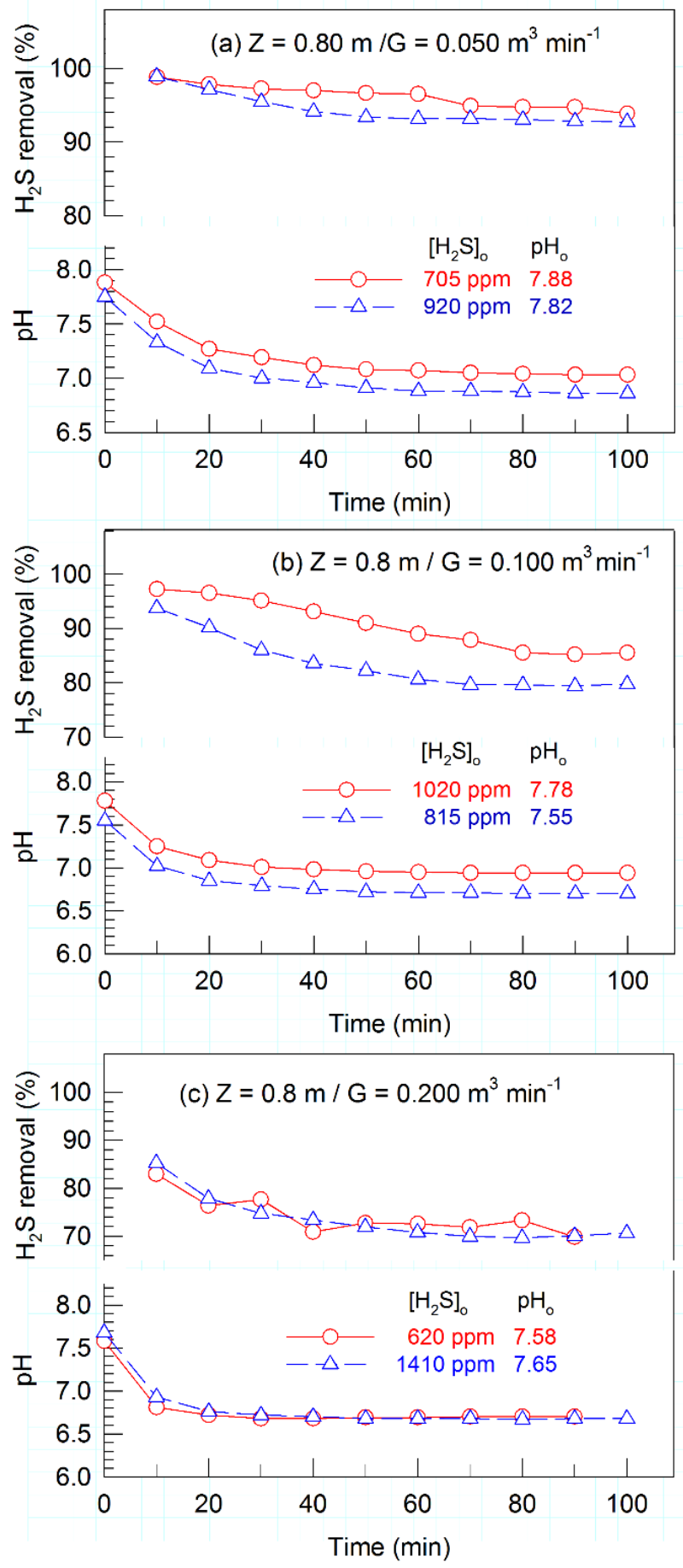

Fig. 3. Time variations of $\mathrm{H}_{2} \mathrm{~S}$ removal and liquid $\mathrm{pH}$ with operations of liquid depth $\mathrm{Z}=0.8 \mathrm{~m}$ and gas injection rate $\mathrm{G}$ of (a) 0.050 , (b) 0.100 , and (c) $0.200 \mathrm{~m}^{3} \mathrm{~min}^{-1}$.

Fig. 5 presents the effects of the influent biogas flow rate on the removal efficiency of $\mathrm{H}_{2} \mathrm{~S}$ and the $\mathrm{pH}$ of the effluent liquid. When $Z$ was $0.80 \mathrm{~m}$, because the $\mathrm{pH}$ of the liquid decreased, the removal efficiency drastically decreased as the gas flow rate increased. When $Z$ was 0.90 and $1.0 \mathrm{~m}$, higher liquid $\mathrm{pH}$ values at all gas flow rates caused variations in efficiency; the gas flow rate and liquid level were lower than those when $Z$ was $.8 \mathrm{~m}$. 


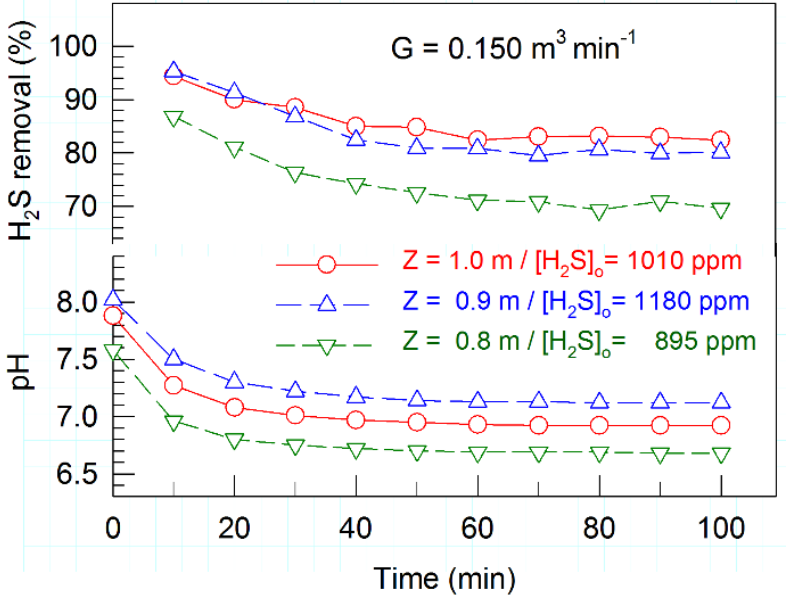

Fig. 4. Time variations of average values of $\mathrm{H}_{2} \mathrm{~S}$ removal and liquid $\mathrm{pH}$ with operations of gas injection rate $\mathrm{G}=$ $0.150 \mathrm{~m}^{3} \mathrm{~min}^{-1}$ and liquid depths $\mathrm{Z}=$ of $0.8,0.9$, and $1.0 \mathrm{~m}$.
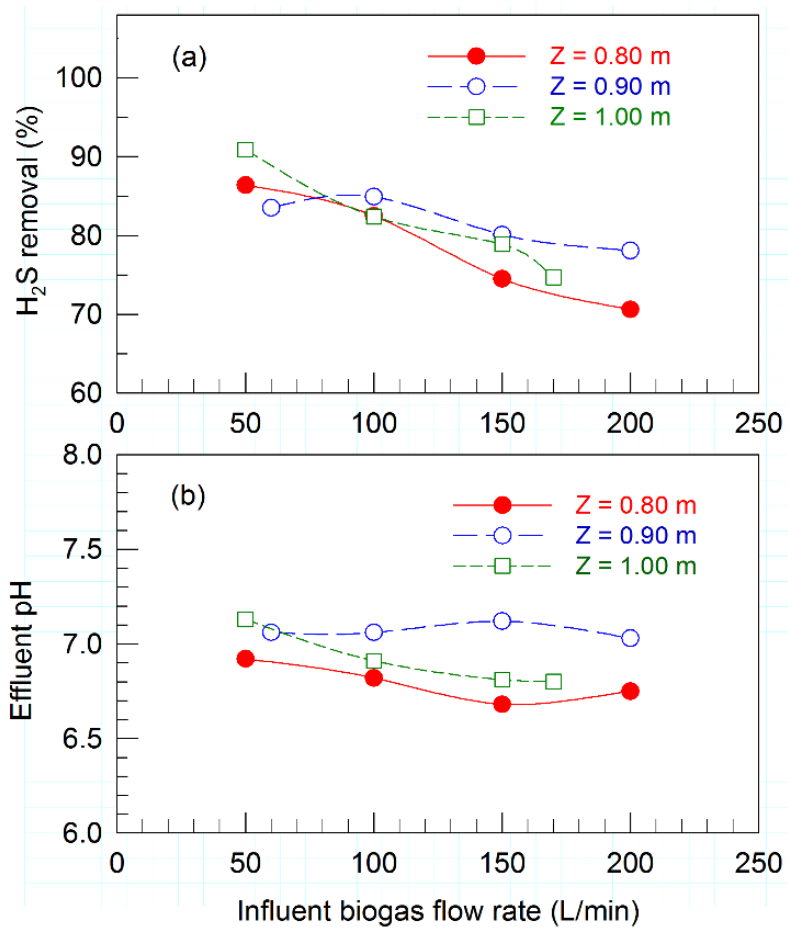

Fig. 5. Influences of influent biogas flow rate on the $\mathrm{H}_{2} \mathrm{~S}$ removal and effluent liquid $\mathrm{pH}$ at quasi-steady states.

\section{Mechanisms of $\mathrm{H}_{2} \mathrm{~S}$ removal Other than Water Absorption}

As detailed in Table 2, the oxygen concentrations in the influent biogas added to and the effluent biogas derived from the absorbing liquid were $0.53 \% \pm 0.22 \%$ and $0.50 \% \pm 0.22 \%$, respectively. On average, only $0.03 \%$, or $300 \mathrm{ppm}$, of $\mathrm{O}_{2}$ in the biogas was absorbed by the absorbing liquid, and the oxygen could be used to oxidize either $150 \mathrm{ppm}$ of $\mathrm{H}_{2} \mathrm{~S}$ that was transferred from the biogas (according to $\mathrm{HS}^{-}+2 \mathrm{O}_{2} \rightarrow$ $\mathrm{HSO}_{4}^{-}$) or $600 \mathrm{ppm}$ of $\mathrm{H}_{2} \mathrm{~S}$ (according to $2 \mathrm{HS}^{-}+\mathrm{O}_{2} \rightarrow 2 \mathrm{~S}^{0}$ $\left.+2 \mathrm{OH}^{-}\right)($González-Sánchez and Revah, 2007). This amount of $\mathrm{H}_{2} \mathrm{~S}(150-600 \mathrm{ppm})$ was approximately $14 \%-55 \%$ of
$1,090 \pm 300$ ppm of $\mathrm{H}_{2} \mathrm{~S}$ in the influent biogas. $\mathrm{DO}$ in the influent absorbing liquid at an average flow rate of $25 \mathrm{~L} \mathrm{~min}^{-1}$ was approximately $1 \mathrm{mg} \mathrm{L}^{-1}$, and the total DO input to the

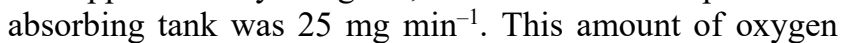
could oxidize 13 and $53 \mathrm{mg} \mathrm{H}_{2} \mathrm{~S} \mathrm{~min}^{-1}$ (according to the two aforementioned equations), respectively. The DO could oxidize $95-380 \mathrm{ppm}$ of $\mathrm{H}_{2} \mathrm{~S}$ that was absorbed from the biogas at an influent flow rate of $100 \mathrm{~L} \mathrm{~min}^{-1}$, at, for example, approximately $30^{\circ} \mathrm{C}$. Therefore, at most $245-980 \mathrm{ppm}$ of $\mathrm{H}_{2} \mathrm{~S}$ that was absorbed from the biogas with $1,090 \mathrm{ppm}_{2} \mathrm{~S}$ could possibly be oxidized to elementary sulfur or various oxidation compounds of sulfur (such as $\mathrm{S}_{2} \mathrm{O}_{3}{ }^{2-}, \mathrm{SO}_{3}{ }^{2-}$, and $\mathrm{SO}_{4}{ }^{2-}$ ) (Cline and Richards, 1969; Jorgensen, 1990; Zhang et al., 2008). Therefore, the $\mathrm{H}_{2} \mathrm{~S}$ removal mechanisms in this process might include liquid absorption and chemical or biological oxidation.

There existed biological activity in the influent scrubbing liquid drawn from one of the aeration ponds for treating the dairy wastewater, and the activities responded for the microbial oxidation of the absorbed $\mathrm{H}_{2} \mathrm{~S}$. The aeration ponds were operated 24 hours a day and biological activity was kept at a quasi-steady state. The biological activity in the scrubbing liquid were assumed to be constant throughout the 100-minute operation time.

\section{Adjustment of Liquid pH to Improve $\mathrm{H}_{2} \mathrm{~S}$ Removal Efficiency}

Fig. 6 details the effect of liquid $\mathrm{pH}$ on the removal efficiency of $\mathrm{H}_{2} \mathrm{~S}$ when $Z$ is $0.8 \mathrm{~m}$. The $\mathrm{pH}$ was adjusted when the system reached a quasi-steady state. Data in Fig. 6 indicate that the condition where $G$ is $0.100 \mathrm{~m}^{3} \mathrm{~min}^{-1}$ and the effluent or absorbing liquid was of $\mathrm{pH} 8$ resulted in $99 \%$ removal of $760 \mathrm{ppm} \mathrm{H}_{2} \mathrm{~S}$ in the influent gas. At $\mathrm{pH} \mathrm{8}$, the $\mathrm{H}_{2} \mathrm{~S}$ removal efficiency decreased as the gas injection rate increased, possibly because of a decrease in the mass transfer rate of the gaseous $\mathrm{H}_{2} \mathrm{~S}$ to the scrubbing liquid at the higher gas injection rate, as Eq. (1) shows. The additional increase in the $\mathrm{H}_{2} \mathrm{~S}$ removal rate when the liquid $\mathrm{pH}$ was adjusted to 8.5 was less than that when the liquid $\mathrm{pH}$ was adjusted to 8 . Supplementation with an additional caustic solution to increase the $\mathrm{pH}$ to 8.5 was unnecessary.

\section{Limitation of $\mathrm{H}_{2} \mathrm{~S}$ Transfer Rate}

According to data in Fig. 6, the $\mathrm{H}_{2} \mathrm{~S}$ removal rates were $>94 \%$ when $\mathrm{G}$ was $\leq 0.150 \mathrm{~m}^{3} \mathrm{~min}^{-1}$ and the $\mathrm{pH}$ of the absorbing water was adjusted to 8.0 or 8.5 . The mass transfer rate, $\mathrm{R}$, of gaseous $\mathrm{H}_{2} \mathrm{~S}$ to the scrubbing liquid can be described as $\mathrm{R}=\mathrm{K}_{\mathrm{Ga}}(\mathrm{C}-m x)$ as shown in Eq. (1). Table 3 shows dependence of $f$ on water $\mathrm{pH}$. Water with a higher $\mathrm{pH}$ gives a lower $\left[\mathrm{H}_{2} \mathrm{~S}\right]$ or $x$ value which favors the absorption of gaseous $\mathrm{H}_{2} \mathrm{~S}$. When the scrubbing liquid $\mathrm{pH}$ is $>8.0, m x$ $<<\mathrm{C}$, and $\mathrm{R}$ equals approximately $\mathrm{K}_{\mathrm{Ga}} \mathrm{C}$. This explains why when $\mathrm{pH}$ is $>8$, the $\mathrm{H}_{2} \mathrm{~S}$ removal efficiency could reach a high value at the fixed operating conditions of liquid depth, liquid temperature, liquid flow rate, and biogas flow rate. In addition, sparging holes with $2.0 \mathrm{~mm}$ (rather than $1.0 \mathrm{~mm}$ in the present study) in diameter had been used by authors and much lower $\mathrm{H}_{2} \mathrm{~S}$ removal efficiencies got due to their lower gas-liquid interfacial area (a) available for the transfer. 

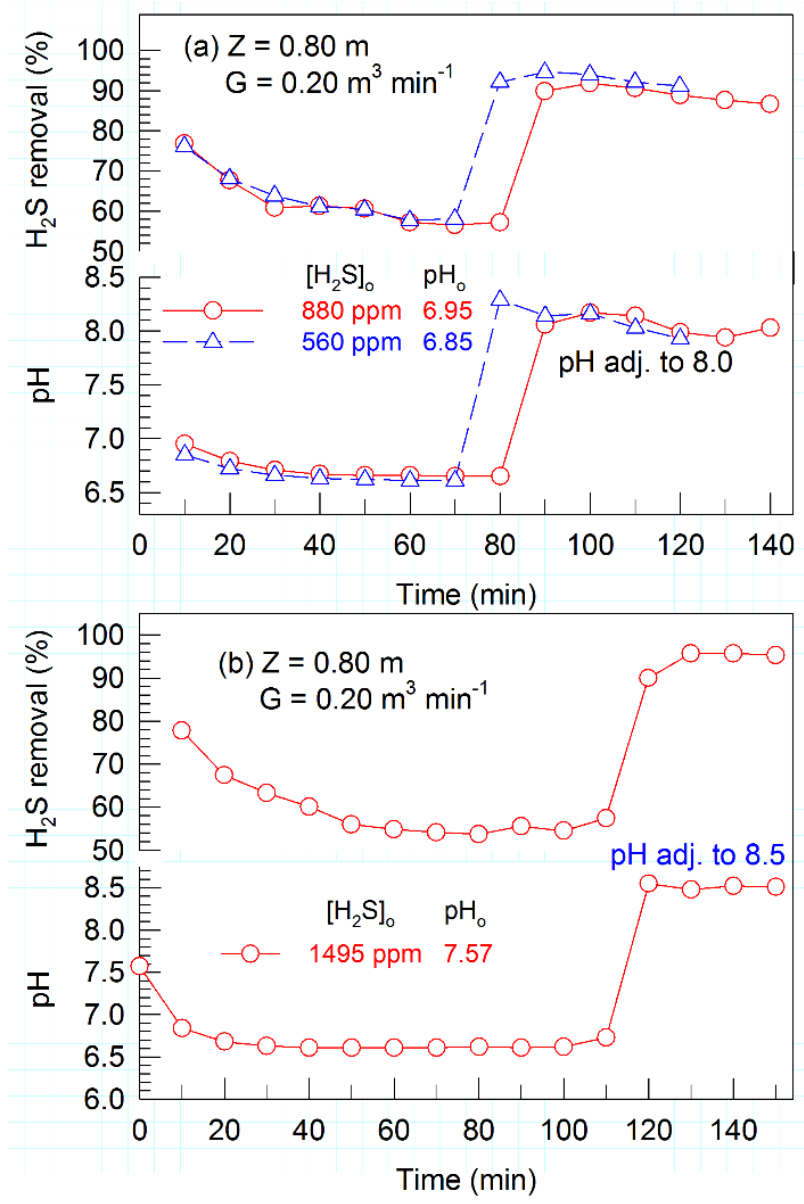

Fig. 6. Time variations of $\mathrm{H}_{2} \mathrm{~S}$ removal and liquid $\mathrm{pH}$ with operations of liquid depth $\mathrm{Z}=0.8 \mathrm{~m}$ and gas injection rate $\mathrm{G}$ $=0.20 \mathrm{~m}^{3} \mathrm{~min}^{-1}$ and liquid $\mathrm{pH}$ adjusted to (a) 8.0 after time of 70-80 minutes and (b) 8.5 after time of 110 minutes.

\section{Effects of Biogas Absorption on the Basicity of the Scrubbing Liquid}

Table 1 reveals that COD, SS, and TS did not differ significantly between the influent and effluent scrubbing liquids for $\mathrm{H}_{2} \mathrm{~S}$ absorption. The decrease in the $\mathrm{pH}$ of the effluent liquid that was caused by the absorption of $\mathrm{H}_{2} \mathrm{~S}$ and $\mathrm{CO}_{2}$ from the injected biogas reduced the $\mathrm{H}_{2} \mathrm{~S}$ removal efficiency. Temperature may affect the $\mathrm{H}_{2} \mathrm{~S}$ removal rate. The influent gas temperatures were between $33-47^{\circ} \mathrm{C}$ from April to September and $20-35^{\circ} \mathrm{C}$ from October to March. The effluent gas temperatures were $2-5^{\circ} \mathrm{C}$ lower than the influent ones due to a chilling effect from the gas bubbling through the scrubbing liquid. The scrubbing liquid temperatures were $30-34^{\circ} \mathrm{C}$ from April to September and $24-30^{\circ} \mathrm{C}$ from October to March. No temperature control for both the biogas and scrubbing liquid was conducted during the tests. Similar studies have not considered biogas and scrubbing water temperatures (Hagen et al., 2001; Lien et al., 2014). Tilahun et al. $(2017,2018)$ used membrane contactors to separate $\mathrm{H}_{2} \mathrm{~S}$ from biogas; however, the mechanism of $\mathrm{H}_{2} \mathrm{~S}$ removal is its diffusion through a porous membrane rather than a gas film (as in this study). The effects of biogas and scrubbing liquid temperatures on $\mathrm{H}_{2} \mathrm{~S}$ removal will be investigated in a further study.

According to Fig. 3(c), when $G$ was $0.200 \mathrm{~m}^{3} \cdot \mathrm{min}^{-1}$, the mean effluent gas temperature was $38^{\circ} \mathrm{C}$, the average influent $\mathrm{H}_{2} \mathrm{~S}$ concentration was $1,410 \mathrm{ppm}$, and the influent $\mathrm{H}_{2} \mathrm{~S}$ mass flow rate was $11.1 \mathrm{mmol} \mathrm{min}^{-1}\left(1,410 \mathrm{ppm} \times 0.200 \mathrm{Am}^{3} \mathrm{~min}^{-1}\right.$ $\times 10^{-6} \mathrm{ppm}^{-1} \times 273 \mathrm{Nm}^{3} /[38+273] \mathrm{Am}^{3} / 22.4 \mathrm{Nm}^{3} \mathrm{kmol}^{-1}=$ $11.1 \mathrm{mmol} \mathrm{min}^{-1}$ ). Total absorption of the injected $\mathrm{H}_{2} \mathrm{~S}$ into the influent liquid at a flow rate of $25 \mathrm{~L} \mathrm{~min}^{-1}$ may have reduced the water basicity by $0.336 \mathrm{meq} \mathrm{L}^{-1}$ from that of the influent

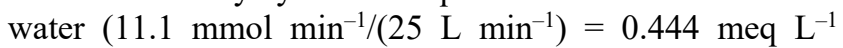
according to $\mathrm{H}_{2} \mathrm{~S}_{(\mathrm{aq})} \rightarrow \mathrm{HS}^{-}+\mathrm{H}^{+}$). The decrease in basicity was only $7.25 \%$ of that of $6.13 \pm 0.3 \mathrm{meq} \mathrm{L}^{-1}$ in the influent liquid when titrated to $\mathrm{pH} 7$ (Table 1).

The major drop in the basicity of the scrubbing liquid is caused by the absorption of $\mathrm{CO}_{2}$ from the biogas. Fig. 7 presents the time variations in the concentrations of $\mathrm{CO}_{2}$ in the influent and effluent gases and the $\mathrm{pH}$ of the effluent liquid when $Z, G$, and $L$ were $0.8 \mathrm{~m}, 0.16 \mathrm{~m}^{3} \mathrm{~min}^{-1}$, and $25 \mathrm{~L} \mathrm{~min}^{-1}$, respectively. In the quasi-steady state, an average of approximately $2.33 \%$ of the $\mathrm{CO}_{2}$ in the influent biogas was absorbed into the liquid. The absorbed $\mathrm{CO}_{2}$ mass flow rate was $146 \mathrm{mmol} \mathrm{min}^{-1}\left(2.33 \% \times 0.160 \mathrm{Am}^{3} \mathrm{~min}^{-1} \times 10^{-2} \%{ }^{-1} \times 273\right.$ $\left.\mathrm{Nm}^{3} /\left[(38+273) \mathrm{Am}^{3} /\left(22.4 \mathrm{Nm}^{3} \mathrm{kmol}^{-1}\right)\right]=146 \mathrm{mmol} \mathrm{min}^{-1}\right)$. The absorption of the $\mathrm{CO}_{2}$ into the influent liquid at a flow rate of $25 \mathrm{~L} \mathrm{~min}^{-1}$ reduced the basicity by $5.84 \mathrm{meq} \mathrm{L}^{-1}$ from that of the influent liquid $\left(146 \mathrm{mmol} \mathrm{min}^{-1} /\left(25 \mathrm{~L} \mathrm{~min}^{-1}\right)=\right.$ 5.84 mmol L ${ }^{-1}=5.84$ meq L ${ }^{-1}$, according to $\mathrm{CO}_{2(\mathrm{aq})}+\mathrm{H}_{2} \mathrm{O} \rightarrow$ $\mathrm{HCO}_{3}{ }^{-}+\mathrm{H}^{+}$). This basicity of $5.84 \mathrm{meq} \mathrm{L}^{-1}$ was approximately $95 \%$ of $6.13 \pm 0.33 \mathrm{meq} \mathrm{L}^{-1}$ in the influent liquid (Table 1). The decrease in $\mathrm{pH}$ is attributable to $\mathrm{CO}_{2}$ absorption into the scrubbing liquid, which reduced the $\mathrm{H}_{2} \mathrm{~S}$ removal efficiency. Therefore, with an increase in $\mathrm{G} / \mathrm{L}$ (gas/liquid rate ratio), the scrubbing liquid absorbs a much more $\mathrm{CO}_{2}$ from the biogas and this results in the decrease in liquid $\mathrm{pH}$ and $\mathrm{H}_{2} \mathrm{~S}$ removal efficiency. Fig. 5 displays that at a constant $\mathrm{L}$ of $25 \mathrm{~L} \mathrm{~min}^{-1}$, $\mathrm{H}_{2} \mathrm{~S}$ removal efficiencies decreased with increasing gas flow rate $(\mathrm{G})$ or $\mathrm{G} / \mathrm{L}$, and decreasing $\mathrm{pH}$. With $\mathrm{G}$ extra plotting to

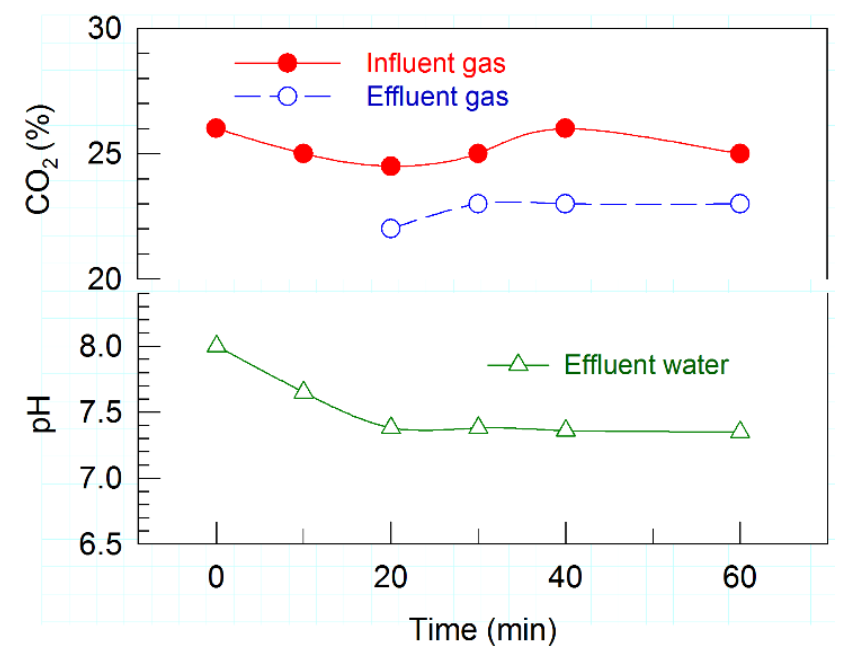

Fig. 7. Time variations of $\mathrm{CO}_{2}$ concentrations in the influent and effluent gases and effluent liquid $\mathrm{pH}$ (Liquid depth $\mathrm{Z}=$ $0.8 \mathrm{~m}$, gas injection rate $\mathrm{G}=0.16 \mathrm{~m}^{3} \mathrm{~min}^{-1}$, and water flow rate $\mathrm{L}=25 \mathrm{~L} \mathrm{~min}^{-1}$ ). 
0 at $\mathrm{Z}=1.00 \mathrm{~m}, \mathrm{H}_{2} \mathrm{~S}$ might approach to $100 \%$ as shown in Fig. 3(a). The attribution of $\mathrm{CO}_{2}$ in the biogas to the lowering liquid $\mathrm{pH}$ also supports the results that the $\mathrm{H}_{2} \mathrm{~S}$ removal efficiencies were nearly independent with the influent $\mathrm{H}_{2} \mathrm{~S}$ concentrations of $<1,500 \mathrm{ppm}$.

\section{Comparisons of Biogas Desulfurization Methods}

Table 4 compares biogas desulfurization methods. Tilahun et al. (2018) used a polydimethylsiloxane membrane contactor for selective $\mathrm{H}_{2} \mathrm{~S}$ removal from the biogas. The $\mathrm{H}_{2} \mathrm{~S}$ and $\mathrm{CH}_{4}$ in the biogas diffused through the membrane to an absorbing liquid. The results revealed that at the lowest loading rate $\left(91 \mathrm{mg} \mathrm{H}_{2} \mathrm{~S} \mathrm{~m}^{-2} \mathrm{~h}^{-1}\right)$, absorption efficiencies of more than $98 \%$ for $\mathrm{H}_{2} \mathrm{~S}$ and $59 \%$ for $\mathrm{CO}_{2}$ were achieved. Increasing the absorbing liquid $\mathrm{pH}$ (from 7 to 10 ) and the loading rate (from 91 to $355 \mathrm{mg} \mathrm{H}_{2} \mathrm{~S} \mathrm{~m}^{-2} \mathrm{~h}^{-1}$ ) increased the $\mathrm{H}_{2} \mathrm{~S}$ absorption capacity. Tilahun et al. (2017) also used a hybrid membrane gas absorption and bio-oxidation process for the removal of hydrogen sulfide from biogas. Membrane processes have promising real scale applications if they are cost-effective.

Unlike the water scrubbing method in which the saturated scrubbing water must be replaced (Lien et al., 2014), an activated sludge mixed liquor for polishing the effluent wastewater from the anaerobic digester(s) was used in the current approach. No additional fresh water is required for this proposed process. The effluent liquid from the simple absorption tank can be further treated to oxidize the absorbed $\mathrm{H}_{2} \mathrm{~S}$ to sulfate, which is considerably less harmful to aqueous environments than sulfide ions.

Compared with biological approaches such as those involving BFs or BTFs, which require organic or inert packing materials, the proposed method neither requires these materials nor the need to control the microbial activities

Table 4. Comparisons of biogas desulfurization methods.

\begin{tabular}{|c|c|c|c|c|}
\hline Method & Characteristics & Advantages & Limitations & Literature \\
\hline $\begin{array}{l}\text { Addition of } \mathrm{Fe}^{2+} \\
\text { to anaerobic } \\
\text { digester }\end{array}$ & $\begin{array}{l}\mathrm{Fe}^{2+} \text { reacts with } \\
\text { sulfide ions to form } \\
\mathrm{FeS}\end{array}$ & $\begin{array}{l}\mathrm{H}_{2} \mathrm{~S} \text { levels of } 100 \\
\text { to } 150 \mathrm{ppm} \text { in the } \\
\text { biogas can be } \\
\text { reached }\end{array}$ & $\begin{array}{l}\text { When using raw materials } \\
\text { that are rich in sulfur } \\
\text { containing molecules, this } \\
\text { method is rather expensive }\end{array}$ & Hagen et al., 2001 \\
\hline $\begin{array}{l}\text { Chemical } \\
\text { adsorption of } \\
\mathrm{H}_{2} \mathrm{~S} \text { by } \mathrm{Fe}_{2} \mathrm{O}_{3}\end{array}$ & $\begin{array}{l}\text { Oxidation of } \mathrm{H}_{2} \mathrm{~S} \text { to } \\
\mathrm{S} \text { by } \mathrm{Fe}^{3+}\end{array}$ & $\begin{array}{l}\text { High } \mathrm{H}_{2} \mathrm{~S} \text { removal } \\
\text { can be reached }\end{array}$ & $\begin{array}{l}\text { Needs expensive } \\
\text { chemicals and require that } \\
\text { the sulfur slurry that is } \\
\text { formed from hydrogen } \\
\text { sulfide to be handled }\end{array}$ & Hagen et al., 2001 \\
\hline $\begin{array}{l}\text { Chemical } \\
\text { absorption of } \\
\mathrm{H}_{2} \mathrm{~S} \text { by ferric } \\
\text { sulfate }\end{array}$ & Ibid. & Ibid. & Ibid. & Krischan et al., 2010 \\
\hline $\begin{array}{l}\text { Biological } \\
\text { oxidation of } \mathrm{H}_{2} \mathrm{~S}\end{array}$ & $\begin{array}{l}\text { Addition of } 5-10 \% \\
\text { air to the biogas in } \\
\text { a bioreactor to } \\
\text { convert } \mathrm{H}_{2} \mathrm{~S} \text { to } \\
\text { sulfur }\end{array}$ & Ibid. & Ibid. & $\begin{array}{l}\text { Gadre, 1989; Nitta and } \\
\text { Hirura, 1993; Yang and } \\
\text { Allen, 1994; Jensen and } \\
\text { Webb, 1995; Nishimura } \\
\text { and Motoyuki, 1997; } \\
\text { Potivichayanon et al., } \\
\text { 2006; Liang and Liang, } \\
\text { 2013; Lin et al., 2013; } \\
\text { Su et al., 2013; Solcia et } \\
\text { al., 2014; Su et al., } 2014\end{array}$ \\
\hline $\begin{array}{l}\text { Adsorbed on } \\
\text { activated carbon }\end{array}$ & $\begin{array}{l}\text { Addition of air to } \\
\text { the biogas to } \\
\text { catalytically } \\
\text { oxidize } \mathrm{H}_{2} \mathrm{~S} \text { to } \\
\text { sulfur }\end{array}$ & Ibid. & $\begin{array}{l}\text { Saturated carbon is usually } \\
\text { spent without regeneration. }\end{array}$ & $\begin{array}{l}\text { Hagen et al., 2001; } \\
\text { Pipatmanomai et al., } \\
2009\end{array}$ \\
\hline $\begin{array}{l}\text { Membrane } \\
\text { filtration }\end{array}$ & $\begin{array}{l}\text { Selective } \\
\text { membrane filtration } \\
\text { of } \mathrm{H}_{2} \mathrm{~S} \text { and } \mathrm{CO}_{2} \\
\text { from biogas }\end{array}$ & $\begin{array}{l}\text { High } \mathrm{H}_{2} \mathrm{~S} \text { removal } \\
\text { and moderate } \mathrm{CO}_{2} \\
\text { removal can be } \\
\text { reached }\end{array}$ & Cost of & $\begin{array}{l}\text { Tilahun et al., } 2017 \text {, } \\
2018\end{array}$ \\
\hline Water scrubbing & $\begin{array}{l}\text { Use water to scrub } \\
\mathrm{H}_{2} \mathrm{~S} \text { from biogas }\end{array}$ & $\begin{array}{l}\text { Equipment is } \\
\text { simple }\end{array}$ & $\begin{array}{l}\text { Needs replacement and } \\
\text { treatment of saturated } \\
\text { scrubbing water }\end{array}$ & Lien et al., 2014 \\
\hline $\begin{array}{l}\text { Wastewater } \\
\text { scrubbing }\end{array}$ & $\begin{array}{l}\text { Use wastewater in } \\
\text { aeration to scrub } \\
\mathrm{H}_{2} \mathrm{~S} \text { from biogas }\end{array}$ & $\begin{array}{l}\text { Equipment is } \\
\text { simple }\end{array}$ & $\begin{array}{l}\text { Needs enough wastewater } \\
\text { to reach a high } \mathrm{H}_{2} \mathrm{~S} \\
\text { removal }\end{array}$ & Present study \\
\hline
\end{tabular}


of the biofilms that are either inside or attached to the packing materials. In addition, the $\mathrm{H}_{2} \mathrm{~S}$ removal efficiency from BFs may be unstable because of fluctuations in biological activity. The $\mathrm{H}_{2} \mathrm{~S}$ removal efficiency of the proposed method can be stabilized by maintaining the scrubbing liquid depth, liquid $\mathrm{pH}$, and the ratio of gas flow rates to liquid flow rates. However, the proposed method requires at least one activated aeration tank, a low-head liquid pump to deliver the scrubbing liquid, and a medium-pressure (approximately 0.1 bar) or a $1,000 \mathrm{~mm}$ water head blower to sparge the digester gas into the scrubbing liquid. The operating electrical energy cost of the proposed method is also higher than that of the method that uses biofilters.

Compared with the activated sludge tank bubbling processes (Shimko et al., 1987; Sublette et al., 1994; Amano et al., 1999; Chou et al., 2010), the proposed method requires no nutrients to sustain microbial growth and activity. In the proposed method, no attention is required to be paid to the health of the microorganisms to maintain $\mathrm{H}_{2} \mathrm{~S}$ removal efficiency.

Biological processes such as those cited in Muñoz et al. (2015) may have $\mathrm{H}_{2} \mathrm{~S}$ removal efficiencies higher than $90 \%$. Compared with biological methods, the main limitation of the proposed process is its increased cost from additional chemicals (caustic soda) that are usually required to adjust the absorbing liquid to a $\mathrm{pH}$ of $>8$ to obtain a $\mathrm{H}_{2} \mathrm{~S}$ removal efficiency of more than $90 \%$. However, this cost can be reduced to as low as zero by increasing the ratio of scrubbing liquid flow rate to gas flow rate, allowing the removal of over $90 \%$ of $\mathrm{H}_{2} \mathrm{~S}$ in the influent biogas. The scrubbing liquid can be drawn from existing biological aeration tank(s) and drained back to the tank(s) to biologically oxidize the absorbed $\mathrm{H}_{2} \mathrm{~S}$ to sulfate ions. The pumping cost should be taken into account.

Khoshnevisan et al. (2017) demonstrated that the sufficient residence time (RT) for biogas in biotrickling filters is a key factor for successful microaerobic desulfurization. A RT of greater than $5 \mathrm{~h}$ yields removal efficiencies (REs) of up to $90 \%$. REs of $88 \%$ and $72 \%$ were obtained when an RT of approximately $2.5 \mathrm{~h}$ was tested. A study demonstrated a successful RE of $96 \%$ under variable RTs (from 59 to $97 \mathrm{~min}$ ). However, a long RT, for example, of $1 \mathrm{~h}$, implies that a big reactor is required to treat a sufficiently large flow of biogas. In the present study, a biogas rate of $200 \mathrm{~L} \mathrm{~min}^{-1}$ requires an absorbing water volume of only $1,100 \mathrm{~L}$ to attain an RE of more than $80 \%$. Data are equivalent to an RT of approximately 5 min.

Another disadvantage of BTFs is the formation of elemental sulfur in the reactors. The sulfur gradually increases the pressure required for driving the gas through the filters and eventually clogs the filters. One approach to solving the clogging problem is to withdraw the accumulated solids from the packing materials after shutting down the filtration systems. The present system has no problems with clogging because most of the absorbed $\mathrm{H}_{2} \mathrm{~S}$ is in $\mathrm{H}_{2} \mathrm{~S}$ and $\mathrm{HS}^{-}$aqueous states. Moreover, the suspended elemental sulfur, if any, flows out with the effluent absorbing liquid.

Pokorná et al. (2015) described microaeration as a straightforward, highly efficient, and economically viable technique for $\mathrm{H}_{2} \mathrm{~S}$ removal from biogas. In the method, sulfide is oxidized to elemental sulfur by the action of sulfide oxidizing bacteria. However, the limitations of microaeration, such as partial oxidation of the soluble substrate, clogging in the walls and pipes by elemental sulfur, and toxicity to methanogens, were noted. The proposed method has no such problems.

\section{Feasibility of the Process and Further Studies}

A tank with a reasonable size and liquid depth is required for the practical application of the proposed method. Recebli et al. (2015) discovered that an average of $25 \mathrm{~kg}$ of manure per day ( $8.44 \%$ dry solids) produced from one bovine animal can generate $0.90 \mathrm{~m}^{3}$ of digester gas per day with $62 \%$ of $\mathrm{CH}_{4}$ at $25-40^{\circ} \mathrm{C}$. Thus, a ranch that has 200 bovine animals can produce $180 \mathrm{~m}^{3}$ of digester gas per day (average: $0.125 \mathrm{~m}^{3} \mathrm{~min}^{-1}$ ) if all the manure is anaerobically fermented. A system size similar to the one tested in the present study can be used to remove $80 \%$ of $\mathrm{H}_{2} \mathrm{~S}$ from the biogas when the scrubbing liquid flow is $25 \mathrm{~L} \mathrm{~min}{ }^{-1}$. The liquid can be introduced from either an aerobic pond or the effluent pond of the wastewater treatment plant for the ranch and discharged back to the aerobic pond to oxidize the absorbed sulfides. The installation cost for the system is around 3,000 USD. The operation consumes electricity for the $1 \mathrm{HP}$ ring blower and $1 \mathrm{HP}$ water pump, both operated at around $50 \%$ capacity. Daily electricity cost is estimated to be around $1.8 \mathrm{USD}$ for $18 \mathrm{kWh}$ electricity. The cost is equivalent to USD 10 for $1,000 \mathrm{~m}^{3}$ of the biogas. The cost is around $3.3 \%$ of USD 300 for $1,000 \mathrm{~m}^{3}$ biogas cost.

This study presents only experimental data and discusses some influencing factors on the $\mathrm{H}_{2} \mathrm{~S}$ removal from the biogas. Based on the data, theoretical analyses should be done in further studies to show quantitatively the influence of the key affecting factors on the $\mathrm{H}_{2} \mathrm{~S}$ removal. In addition, $\mathrm{H}_{2} \mathrm{~S}$ in the biogas from digesters for swine wastes were reported to be as high as 5,000 ppm (Su et al., 2014). Further studies should account for the high $\mathrm{H}_{2} \mathrm{~S}$ concentrations in some biogases.

\section{CONCLUSIONS}

The results revealed that $\mathrm{H}_{2} \mathrm{~S}$ in an anaerobic digester gas can be effectively removed by directly sparging it into a tank that is filled with liquid to a depth of $0.8-1 \mathrm{~m}$. The liquid was obtained from an aerobic pond to treat the effluent from the digester of a dairy wastewater treatment plant. With an influent liquid of $\mathrm{pH} 7.5-7.7$, a flow rate of 23-25 $\mathrm{L} \mathrm{min}^{-1}$, influent biogas flow rates of $0.050-0.200 \mathrm{~m}^{3} \cdot \mathrm{min}^{-1}$, and a $\mathrm{H}_{2} \mathrm{~S}$ concentration of $907 \pm 212 \mathrm{ppm}$, the $\mathrm{pH}$ of the effluent liquid stabilized at 6.6-6.9. The operation conditions were as follows: gas/liquid ratio of $2-8 \mathrm{~m}^{3} \mathrm{~m}^{-3}$ liquid), volumetric gassing intensities of $0.04-0.20 \mathrm{~m}^{3} \mathrm{~m}^{-3}$ liquid $\mathrm{min}^{-1}$ ), and an average tank liquid volume of $1.25 \mathrm{~m}^{3}$. Average $\mathrm{H}_{2} \mathrm{~S}$ REs of $86.4 \%, 82.5 \%, 74.4 \%$, and $70.6 \%$ were obtained at influent biogas rates of $0.050,0.100,0.150$, and $0.200 \mathrm{~m}^{3} \mathrm{~min}^{-1}$, respectively. Data indicate that increasing the $\mathrm{pH}$ of the scrubbing liquid improved the $\mathrm{H}_{2} \mathrm{~S}$ removal efficiency from biogas. $\mathrm{CO}_{2}$ absorption into the scrubbing liquid caused a decrease in the $\mathrm{pH}$, thus decreasing the $\mathrm{H}_{2} \mathrm{~S}$ removal efficiency. 


\section{ACKNOWLEDGMENTS}

The authors would like to thank the Livestock Research Institute, Council of Agriculture, Executive Yuan of Taiwan, R.O.C. for financially supporting this research under Contract No 107AS-2.4.1-LI-L2.

\section{REFERENCES}

Amano, Y., Hirano, T., Kurosawa, H. and Nakamura, K. (1999). Simultaneous removal of hydrogen sulfide and triethylamine by a bacterial deodorant. J. Ferment. Bioeng. 81: 337-342.

American Public Health Association (APHA) (1989). Standard Methods for Examination of Water and Wastewater. 17th Edition, American Public Health Association, Washington DC.

Bellová, R., Melicherčíková D. and Tomčík P. (2016). Calculation of conditional equilibrium in serial multiple precipitation of metal sulfides with hydrogen sulfide stream generated from sodium sulfide: A didactic tool for chemistry teaching. Quim. Nova 39: 765-769.

Beristain-Cardoso, R., Texier, A.C., Sierra, S.Ā., Field, J. A., Elīas RF. and Gómez, J. (2008). Simultaneous sulfide and acetate oxidation under denitrifying conditions using an inverse fluidized bed reactor. J. Chem. Technol. Biotechnol. 83: 1197-1203.

Bielefeldt, A.R. and Stensel, H.D. (1999). Treating VOCcontaminated gases in activated sludge: Mechanistic model to evaluate design and performance. Environ. Sci. Technol. 33: 3234-3240.

Chou, M.S., Perng, C.H., Li, T.H. and Chen, J.Y. (2010). Biooxidation of gaseous hydrogen sulfide in an activated sludge aeration tank. J. Environ. Eng. Manage. 20: 5762.

Cline J.D. and Richards F.A. (1969). Oxygenation of hydrogen sulfide in seawater at constant salinity, temperature and pH. Environ. Sci. Technol. 3: 838-843.

Gadre, R.V. (1989). Removal of hydrogen sulfide from biogas by chemoautotrophic fixed-film bioreactor. Biotechnol. Bioeng. 34: 410-414.

González-Sánchez, A. and Revah, S. (2007). The effect of chemical oxidation on the biological sulfide oxidation by an alkaliphilic sulfoxidizing bacterial consortium. Enzyme Microb. Technol. 40: 292-298.

Hagen, M., Polman, E., Myken, A., Jensen, J., Jönsson, O. and Dahl, A. (2001). Adding gas from biomass to the gas grid. Final Report Contract ENS-51161/99-0034; ALTENER-XVII/4.1030/Z/99-412, Denmark.

Huang, Y., Su, W., Wang, R. and Zhao, T. (2019). Removal of typical industrial gaseous pollutants: from carbon, zeolite, and metal-organic frameworks to molecularly imprinted adsorbents. Aerosol Air Qual. Res. 19: 21302150.

Jensen, A.B. and Webb, C. (1995). Treatment of $\mathrm{H}_{2} \mathrm{~S}$ containing gases: A review of microbiological alternatives. Enzyme Micro. Technol. 1): 2-10.

Jiang, N., Dong, Z., Xu, Y., Yu, F., Yin, S., Zhang, R. and Tang, X. (2018). Characterization of $\mathrm{PM}_{10}$ and $\mathrm{PM}_{2.5}$ source profiles of fugitive dust in Zhengzhou, China. Aerosol Air Qual. Res. 18: 314-329.

Jiang, X., Yan, R. and Tay, J.H. (2009). Simultaneous autotrophic biodegradation of $\mathrm{H}_{2} \mathrm{~S}$ and $\mathrm{NH}_{3}$ in a biotrickling filter. Chemosphere 75: 1350-1355.

Jorgensen, B.A. (1990). Thiosulfate shunt in the sulfur cycle of marine sediments. Science 249: 152-154.

Khoshnevisan, B., Tsapekos, P., Alfaro, N., Díaz, I., FdzPolanco, M., Rafiee, S. and Angelidaki, I. (2017). A review on prospects and challenges of biological $\mathrm{H}_{2} \mathrm{~S}$ removal from biogas with focus on biotrickling filtration and microaerobic desulfurization. Biofuel Res. J. 16: 741750.

Krischan, J., Makaruk, A. and Harasek, M. (2010). Design and scale-up of an oxidative scrubbing process for selective removal of hydrogen sulfide from biogas. $J$. Hazard. Mater. 49: 215-216.

Li, P., Sato, K., Hasegawa, H., Huo, M., Minoura, H., Inomata, Y., Take, N., Yuba, A., Futami, M., Takahashi, T. and Kotake, Y. (2018a). Chemical characteristics and source apportionment of $\mathrm{PM}_{2.5}$ and long-range transport from Northeast Asia Continent to Niigata in Eastern Japan. Aerosol Air Qual. Res. 18: 938-956.

Li, Y.C., Shu, M., Ho, S.S.H., Yu, J.Z., Yuan, Z.B., Liu, Z.F., Wang, X.X. and Zhao, X.Q. (2018b). Effects of chemical composition of $\mathrm{PM}_{2.5}$ on visibility in a SemiRural City of Sichuan Basin. Aerosol Air Qual. Res.18: 957-968.

Liang, M.S. and Liang, Y. (2013). Biological removal of $\mathrm{H}_{2} \mathrm{~S}$ from the livestock manure using a biofilter. Biotechnol. Bioprocess Eng. 18: 1008-1015.

Lien, C.C., Lin, J.L. and Tin, C.H. (2014). Water scrubbing for removal of hydrogen sulfide $\left[\mathrm{H}_{2} \mathrm{~S}\right]$ in biogas from hog farms. J. Agri. Chem. Environ. 3: 1-6.

Lin, W.C., Chen, Y.P. and Tseng C.P. (2013). Pilot-scale chemical-biological system for efficient $\mathrm{H}_{2} \mathrm{~S}$ removal from biogas. Bioresour. Technol. 135: 283-291.

Liu, X. and Wang, R. (2017). An innovative approach to oxidative removal of hydrogen sulfide using the solution of peroxo heteropolyacid. Aerosol Air Qual. Res. 17: 1341-1346.

Liu, X. and Wang, R. (2019). Study on macro kinetics of the desulfurization processes of heteropoly compounds in ionic liquids and aqueous solutions. Aerosol Air Qual. Res. 19: 2899-2907.

Mao, J., Ma, Y., Zang, L., Xue, R., Cong Xiao, C. and Ji, D. (2020). Efficient adsorption of hydrogen sulfide at room temperature using fumed silica-supported deep eutectic solvents. Aerosol Air Qual. Res. 20: 203-215.

Muñoz, R., Meier, L., Diaz, I. and Jeison, D. (2015). A review on the state-of-the-art of physical/chemical and biological technologies for biogas upgrading. Rev. Environ. Sci. Biotechnol. 14: 727-759.

Nishimura, S. and Motoyuki, Y. (1997). Removal of hydrogen sulfide from an anaerobic biogas using a bioscrubber. Water Sci. Technol. 36: 349-356.

Nitta, M. and Hirura, H. (1993). Biofiltration system for gasdeodoring. J. Bioeng. 3: 29-33.

Pei, X and Wang, R. (2019). Desulfurization performance of 
rare earth mono-substituted heteropoly compounds. Aerosol Air Qual. Res. 19: 2888-2898.

Pipatmanomai, S., Kaewluan, S. and Vitidsant, T. (2009). Economic assessment of biogas-to-electricity generation system with $\mathrm{H}_{2} \mathrm{~S}$ removal by activated carbon in small pig farm. Appl. Energy 86: 669-674.

Pokorná, L., Bartacek, J., Díaz, I., Jeison, D., Volcke., E. and Jenicek P. (2015). Microaeration for hydrogen sulfide removal during anaerobic treatment: A review. Rev. Environ. Sci. Biotechnol. 14: 703-725.

Potivichayanon, S., Pokethitiyook, P. and Kruatrachue. M. (2006). Hydrogen sulfide removal by a novel fixed-film bioscrubber system. Process Biochem. 41: 708-715.

Recebli, Z., Selimli, S., Ozkaymak, M. and Gonc, O. (2015). Biogas production from animal manure. J. Energy Sci. Technol. 10: 722-729.

Seadi, T.A., Rutz, D., Prassl, H., Köttner, M., Finsterwalder, T., Volk, S. and Janssen, R. (2008). Biogas handbook, University of Southern Denmark Esbjerg, Niels Bohrs Vej 9-10, DK-6700 Esbjerg, Denmark 41.

Shimko, I.G., Spasov, V.A., Chinennaya, S.K., Zakirova, R.I., Tananina, I.N., Perchugov, Y.G. and Pavlova, O.I. (1987). Biochemical methods of freeing gas-air mixtures from sulfur containing compounds, Translated from Khimicheskie Volokna 6: 7-10.

Smith, S.A. and Ndegwa, P.M. (2012). Hydrogen sulfide concentrations in biogas from diary manure digesters. In Department of ecology report to the legislature: Diary Manure anaerobic digesters. Newman, A. (Ed.), Air Quality Program Washington State Department of Ecology, Olympia, Washington, USA.

Solcia, R.B., Ramīez, M., Fernāndez, M., Cantero, D. and Bevilaqua, D. (2014). Hydrogen sulphide removal from air by biotrickling filter using open-pore polyurethane foam as a carrier. Biochem. Engrg. J. 84: 1-8.

Su, J.J., Chang, Y.C., Chen, Y.J., Chang, K.C. and Lee S.Y. (2013). Hydrogen sulfide removal from livestock biogas by a farm-scale bio-filter desulfurization system. Water Sci. Technol. 67: 1288-1293.

Su, J.J., Chen, Y.J. and Chang, Y.C. (2014). A study of a pilot-scale biogas bio-filter system for utilization on pig farms. J. Agri. Sci. 152: 217-224.

Sublette, K.L., Hesketh, R.P. and Hasan, S. (1994). Microbial oxidation of hydrogen sulfide in a pilot-scale bubble column. Biotechnol. Progr. 10: 611-614.

Sun, J., Zhou, J., Shang, C. and Kikkert, G.A. (2014).
Removal of aqueous hydrogen sulfide by granular ferric hydroxide-kinetics, capacity and reuse. Chemosphere 117: 324-329.

Syed, M., Soreanu, G., Falletta, P. and Béland, M. (2006). Removal of hydrogen sulfide from gas streams using biological processes - A review. Can. Biosyst. Eng. 48: 2.1-2.14.

Tilahun, E., Bayrakdar, A., Sahinkaya, E. and Çalli, B. (2017). Performance of polydimethylsiloxane membrane contactor process for selective hydrogen sulfide removal from biogas, Waste Manage. 61: 250-257.

Tilahun, E., Sahinkaya, E. and Çalli, B. (2018). A hybrid membrane gas absorption and bio-oxidation process for the removal of hydrogen sulfide from biogas. Int. Biodeterior. Biodegrad. 127: 69-76.

Truong, L.V.A. and Abatzoglou, N. (2005). A $\mathrm{H}_{2} \mathrm{~S}$ reactive adsorption process for the purification of biogas prior to its use as a bioenergy vector. Biomass Bioenergy 29: 142151.

Tseng, Y.L., Yuan, C.S., Bagtasa, G., Chuang, H.L. and Li, T.C. (2019). Inter-correlation of chemical compositions, transport routes, and source apportionment results of atmospheric $\mathrm{PM}_{2.5}$ in Southern Taiwan and the Northern Philippines. Aerosol Air Qual. Res. 19: 2645-2661.

Widiana, D.R., Wang, Y.F., You, S.J., Yang, H.H, Wang, L.C., Tsai, J.H. and Chen, H.M. (2019). Air pollution profiles and health risk assessment of ambient volatile organic compounds above a municipal wastewater treatment plant, Taiwan. Aerosol Air Qual. Res. 19: 375-382.

Yang, Y. and Allen, E.R. (1994). Biofiltering control of hydrogen sulfide 1 . Design and operational parameters. $J$. Air Waste Manage. 44: 863-868.

Zhang, L., Schryver, P.D., Gusseme, B.D., Muynck, W.D., Boon, N. and Verstraete, W. (2008). Chemical and biological technologies for hydrogen sulfide emission control in sewer systems: a review. Water Res. 42: 1-12.

Zhang, Y.B., Wang, Y.L., Li, W.H., Bao, L.N., Wang, L.H., Huang, X.H. and Huang, B. (2018). Biogas emission from an anaerobic reactor. Aerosol Air Qual. Res. 18: 14931502.

Received for review, December 27, 2019

Revised, February 17, 2020

Accepted, February 17, 2020 